\title{
Asymmetric Information and Consumer Demand
}

\author{
Ismagilova G. N. ${ }^{1}$, Danilina E. I. ${ }^{2}$, Gafurov I. R. ${ }^{1}$, Ismagilov R. I. ${ }^{1}$ \& Safiullin L. N. ${ }^{1}$ \\ ${ }^{1}$ Kazan Federal University, 18 Kremlyovskaya St., Kazan, Russian Federation \\ ${ }^{2}$ Moscow State University of Instrument Engineering and Computer Science, Russian Federation \\ Correspondence: Ismagilova G. N., Kazan Federal University, 18 Kremlyovskaya St., Kazan 420008, Russian \\ Federation. E-mail: lenar_s@mail.ru
}

Received: August 20, 2014 Accepted: September 8, 2014 Online Published: November 27, 2014

doi:10.5539/ass.v10n24p203 URL: http://dx.doi.org/10.5539/ass.v10n24p203

\begin{abstract}
In the paper study the peculiarities of the formation the consumer demand for durable goods, the so-called «experience goods» in markets with asymmetric information. In the known literature sources studying of the demand is based on the assumption that at the moment of the purchase of goods and services people know exactly what price they are willing to pay for them and what utility they are going to obtain using those goods and services. Consider the signal model in which the initial price and advertising expenditures are the signals of the quality influencing the formation of the demand for new goods offered by the company of unknown quality through consumer behavior. The basis of this model is the study of producers by consumers, acquisition of knowledge, information about price and quality, as well as their use in order to determine the market share of high-quality goods and low-quality goods in the asymmetry of information.
\end{abstract}

Keywords: consumer demand, durable goods, costs

\section{Introduction}

We study the peculiarities of the formation the consumer demand for durable goods, the so-called «experience goods» in markets with asymmetric information.

Under the durable goods we mean goods which have a long service life and which cannot be used immediately, like, for instance, food. Durable goods have some characteristics of capital goods due to their property to create a flow of services during the period of their service, and not to provide an only service during a single act of consumption. That's why, in practice, it is advisable, in our opinion, though conditionally, but to split-nondurable goods, durable goods, and capital goods (Marshall, 1890; Averianov, 2013).

There is well known an existence of many consumer markets, the characteristics of the goods on which consumers found out only after their purchase and consumption process. This is the case with electric lights, furniture, used cars, washing machines, vacuum cleaners, refrigerators, i.e. any other durable goods. These products form a wide class of «experience goods ». There are also markets in which characteristics such as «quality» of products are tested rarely, even in the process of consumption (quantity of fluoride and abrasives in toothpaste, the amount of vitamin $\mathrm{C}$ in the ascorbic acid, timeliness of medical intervention). This type of goods forms the class of the «search goods».

In the known literature sources studying of the demand is based on the assumption that at the moment of the purchase of goods and services people know exactly what price they are willing to pay for them and what utility they are going to obtain using those goods and services (Marrero, 2007; Morgan, 2001). For example, when a consumer buys a chocolate bar, he realizes how much money he will pay for this bar of chocolate, and knows how much he likes chocolate. If a consumer buys a video recorder, car, washing machine or any other durable goods, the situation is different. In each of these cases, consumers purchase the goods that will be used for a long time and, therefore, the more they look into the future, they less can say, what would be the balance of costs and benefits of the purchasing this product.

\section{Method}

Consider the case of a washing machine, the purchase of which will cost 500 euro. If he pays cash, the structure of his momentary costs will not include any uncertainty, the sum will be equal to 500 euro. But washing machine can be broken. It is possible that in two years he will have to pay for its repair 100 euro. It's impossible to predict 
these things but if it happens, he will have to pay the price, just like he had to pay 500 euro when buying a washing machine. In other words, when he buys a washing machine, the full price he will have to pay for the product during the period of its use, is uncertain (Panasyuk, 2013).If the costs of this washing machine are uncertain, the benefits of its purchase and use are also uncertain. Perhaps the reason of his desire to buy a washing machine was an analysis of the brochure of the manufacturer or the watching TV or magazine advertising, etc. But after temporary using of this product the consumer may find its advantages and disadvantage, which were not suspected. For example, the machine does not dry his clothes as he counted on it, furthermore, the car makes much noise, it leaks, the machine door is closed too tightly and so on, thus the purchase of durable goods is associated with the uncertainty. The same can be said about the acquisition of property, regardless of whether it is physical property (e.g., estate property) or about financial property (e.g., shares). In the case of purchase of the property the uncertainty is associated with the future price of it, the direction of change of which the consumer cannot know exactly.

In economy based on knowledge, regarding durable goods, i.e. «experience goods» and «search goods», the main issues are demand, supply, selection of goods, information, and knowledge. Furthermore, the peculiarity of the market of mentioned goods is a typical case when the buyer evaluates the quality of the goods statistically and the seller knows the quality of each item individually. Demand for durable goods $Q^{D}$ mostly depends on two factors - the price $\mathrm{p}$, and the average quality of $\mathrm{g}$, i.e., the function of demand depends on two variables $Q^{D}=Q$ $(\mathrm{p}, \mathrm{g})$. As a supply $\mathrm{S}$, and the average quality of the product depends on the price, in other words, $\mathrm{g}=\mathrm{g}(\mathrm{p})$ and $Q^{S}=Q^{S}(p)$. By reducing the prices usually the quality and supply are decreased.

High quality goods $(\mathrm{k})$ and low quality goods (n) have respective market shares have $v \mathrm{kS}$ and $\mathrm{vnS}$ which are probabilities and, hence, there is the following correlation: $\mathrm{vnS}=1-\mathrm{vkS}$. Market supply of goods is formed from two groups with high and low quality level described weighted sum of two functions of supply

$$
Q^{S}(p)=v_{k}^{S} Q_{k}^{S}(p)+\left(1-v_{k}^{S}\right) Q_{H}^{S}(p)
$$

where market shares are weighting coefficients,

$Q_{k}^{S}=Q_{k}^{S}(p)$, if $g_{0} \leq g \leq 1 u Q_{u}^{S}=Q_{u}^{S}(p)$, if $0 \leq g \leq g_{0}$ are functions of supply of high quality goods and low quality goods.

Consumers don't know at the moment of purchase about both the level of quality of the purchased product and its market share. They make a selection among goods of different quality formed by mixing them in certain proportions to the total number of goods. Owing to that they have to make their own version of the market shares of mentioned goods of high quality $v_{\mathrm{k}}{ }^{\mathrm{D}}$ and low $v$ quality ${ }_{\mathrm{H}}^{\mathrm{D}}$ to which the demand is formed.

$$
Q^{D}(p)=v_{k}^{D} Q_{k}^{D}\left(p, g_{k}\right)+\left(1-v_{k}^{D}\right) Q_{H}^{D}\left(p, g_{H}\right)
$$

where market shares are weighting coefficients,

$Q_{k}{ }^{D}=Q_{k}{ }^{D}\left(p, g_{k}\right)$, if $g_{0} \leq g \leq 1 u Q_{u}{ }^{D}=Q_{u}{ }^{D}\left(p, g_{k}\right)$,if $0 \leq g \leq g_{0}$ are function of demand of high-quality and low-quality goods.

An inequality of market share of the offered and consumed goods of high quality $v_{k}^{D} \neq v_{k}^{S}$ or low quality $v_{\mu}{ }^{D} \neq v_{\mu}{ }^{S}$ forms a market asymmetry of information between producers and consumers.

In our view, the level of asymmetry of information on the market shares can be reduced on the basis of distinguishing high-quality producers and low-quality producers by consumers according their price and advertising signals of quality. This supposition is a consequence of the fact that the producers have no reliable way to provide consumers with this information before they decide to make a purchase. Factors of initial decision of producers to sell goods are the price (p), with which the product appears on the market and the sum of expenses A, additionally spent on advertising, regardless of the optimal level of information to potential consumers about the existence of the price and the quality of goods.

Next, we consider the processes of forming a consumer demand according price signals of quality.

Suppose that all consumers are identical to "taste" and have preferences of utility $U=\Theta g-p$, if they buy the product at the price $p$ with the quality level $g$ and taste $\Theta$, and $U=0$ is otherwise. Consumers at the moment of purchase can't differentiate high-quality and low-quality goods, or gradations of their quality. These goods are the same for them. That's why we can talk about the demand of this product, consisting of two or more levels of quality. Incompleteness of information about a product leads to that consumers have to use their knowledge about the level of quality which different types of goods can be had, and information about that how often customers buy these goods in the market. For example, the high price signalizes about high quality and conversely. Under such conditions, consumer demand is studied and realized by consumers taking into account of prognostics the probability of the presence $v_{\mathrm{k}}$-high quality goods (index - k) and $v_{u}$-low quality goods (index 
- h).

Notoriously, the producers of low quality goods can also increase the price of their goods to the level of prices of high-quality goods. This situation is connected with the study of additional factors increasing the reliability of information about the existence of share of high-quality goods. Therefore, in the process of decision whether to purchase this or that product under uncertain conditions consumers should be more informed about the quality.

\section{Forming of Consumer Demand by Price and Advertising Signals of Quality of Firms}

Consider the signal model in which the initial price and advertising expenditures are the signals of the quality influencing the formation of the demand for new goods offered by the company of unknown quality through consumer behavior. The basis of this model is the study of producers by consumers, acquisition of knowledge, information about price and quality, as well as their use in order to determine the market share of high-quality goods and low-quality goods in the asymmetry of information. This study is one of the demonstrations of economic relations in the process of exchange between consumers and producers under asymmetric information.

It is well known that when a company promotes their own goods in the market, it uses advertising, informing potential customers about existing characteristics and prices of offered goods. Some advertisements contain almost no information apart from the existence of the product itself. This is low-cost advertising. There is highly informative advertising. For example, if the advertising is both a kind of announcement about price and quality characteristics of the product, then this way of transmission of information is high cost. The fact of such high-cost advertising of «experience» or «search» goods along with the announcement of the price may be a signal of their high quality. Rational consumers are well-informed consumers who react positively to the brand of a product and high-quality advertising.

On the other hand, it is possible to explain the reason that advertising should be so profitable to sellers of high-quality goods that they are able to produce high-quality advertising on such scales, which the sellers of low-quality goods don't advertise. Sellers of high-quality goods associate the effectiveness of advertising with a repeatability of purchases of their goods as a result of an experience of consumption.

Recently it was noted by Nelson. He said that a high quality product will generate repeat purchases, therefore the initial sale is more valuable to the manufacturer of high quality products and such firm will wish to spend more money for advertising or something else in order to generate the «initial sale». Apparently, his opinion is followed from the ratio of the quality correlation and the convenience yield of the firm from signaling. Information about benefit of market signals in stimulating consumer demand is noted in the works of M. Spence and A. E. Shastitko, P. Milgrom and J. Roberts.

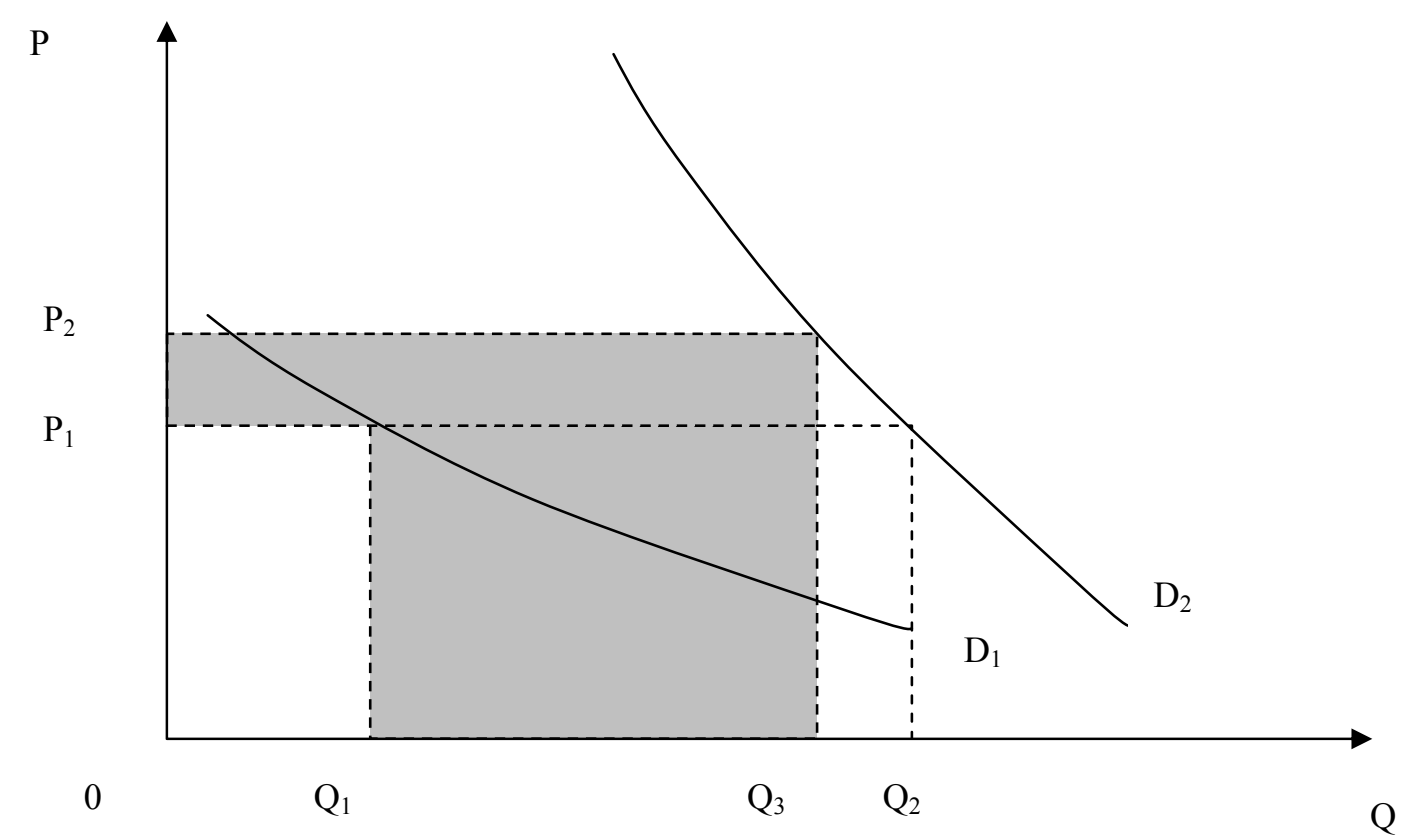

Figure 1. The result of the impact of advertising on the demand curve 
The profit of the firm is equal to $\mathrm{P}=\mathrm{Pi} \operatorname{Pr}+\mathrm{A}$, where profit of the initial sales $\mathrm{Pi}=(\mathrm{P}-\mathrm{AC})$ and repeat sales $\operatorname{Pr}=$ (P-AC) Rv (R), I and R are the volume of initial and repeat purchases, AC is the cost of production, A is advertising costs and $v(R)$ is the probability of repeat purchase, depending on the consumer behavior. It is assumed that the advertising costs are constants that depend on the truth or falsity of the advertising message. False advertising doesn't increase the probability of repeat purchases. The profit of the initial sales, equal to the initial purchases (P - AC) I is a constant, it is increased the amount of profit (profit number) from repeat sales, which are equal to repeat purchases, depending on the probability of repeat purchases.

In our view, the direction of price growth and advertising costs are price and advertising signals of quality for consumers that can be used properly in the formation of consumer demand in markets with incomplete information (including an asymmetric information) by increasing the reliability of determining the probability of the presence of high-quality goods $v_{\mathrm{k}}=v\left(\mathrm{p}_{\mathrm{k}}, \mathrm{A}_{\mathrm{k}}\right)$ and distinguishing them from low-quality goods.

In support of this position consider the dependence of the demand function of the cost of advertising and price of the goods in details:

$$
Q^{D}=a-b P_{k}-c P s+d y+e A_{k}
$$

where the demand for the product $Q^{D}$ is determined by the price of the product- substitute (Ps), by consumer income $y$, the cost of advertising $A_{k}$ of high-quality product, the parameters $(a, b, c, d, e)$ indicate the degree of the influence of relevant factors on the demand. The company sets the price of the product and how much to spend on advertising, and therefore determines the value of $\mathrm{P}$ и $\mathrm{A}_{\mathrm{k}}$.

The purpose of advertising is an increasing sales volume and stimulation of consumer demand, which is expressed by a shift of the demand curve to the right, making the demand less elastic in price points.

Consider the results of the impact of advertising activity of a firm on the demand curve shown in Figure 1. The curve $D_{1}$ represents the initial state of the demand to high-quality goods with the price of $P_{1}$ and sales volume $Q_{1}$. The curve $\mathrm{D}_{2}$ represents the situation after the advertising campaign. The shift to the right means the possibility to sell more goods $\mathrm{Q}_{2}$ at the original price $\mathrm{P}_{1}$. If at the same time it is able to make the demand less elastic, the firm will be able to increase the price of its product to $P_{2}$ increasing sales volume to $Q_{3}$. So, on the graphics we can see that the price can be increased to the level of $P_{2}$, and sales volume to $Q_{3}$, which is much higher than $Q_{1}$. The total profit is showed with a shaded (hatched) area.

The shift of the demand curve to the right will be in the situation if the promotional signals of quality incur much information and provide increased attention of many people to the existence of high-quality goods in the market, and if they lead to an increase of people's desire to have these goods.

The raising of the price elasticity of the demand curve occurs if promotional signals of quality increase customer loyalty to the advertised brand. It is necessary to persuade people (no matter how things are going in reality) to believe that brands of competitors of a firm offer less quality goods. This allows the firm to make the price of its high quality goods higher than the price of its competitors and avoid a significant decline in sales. In this case, the effect of substitution arising as a consequence of the price increase will be insignificant because consumers are sure that the proposed product has no close substitutes.

The more advertising costs associated with the increase of its efficiency, the larger the shift of the demand curve to the right and the smaller will be the price elasticity of the demand. This supports the validity of the proposed expression of demand depending on the cost of advertising $A_{k}$ of a quality product.

That's why consumers must know and find out the following: «Can high-cost pricing signals and high-cost promotional signals are used by «low-quality» producers»?

If the low-quality producers will advertise their low quality goods like high-quality goods, i.e. with the high costs to advertising, it is obvious that they run a risk regarding to future repeat purchases of their low-quality goods by consumers informed about their low-quality goods in the process of using. Because consumers will be able to identify a low quality of a product using it. Furthermore, this market knowledge about the low-quality of the goods will be passed to those buyers who have not used yet the low-quality product.

Therefore rational buyers will more likely to distinguish high-quality producers from low-quality producers and will not make repeat purchases of goods of low-quality manufacturers. Hence, high costs of low-quality producers to advertising will not be justified.

The unequal distribution of information between producers and consumers occurs because of an uncertainty of market shares of high-quality goods and low-quality goods, the overcoming of which is possible owing to a differentiation a «high-quality» manufacturer from a «low-quality» manufacturer by consumers based on the 
sharing of price and advertising signals about a quality of a manufacturer of high-quality goods that performs the same function as the differentiation of high-quality goods and low-quality goods and it's equal to the definition of their market shares. Thus, the sharing of price and advertising signals of product quality by consumers increases the reliability of the market information about shares of (probability) the presence in the market of high-quality and low-quality goods, i.e.

$$
v_{k}^{D}=v_{k}^{S}=Q_{k}^{S} /\left(Q_{k}^{S}+Q_{H}^{S}\right)
$$

This reduces the information asymmetry between consumers and producers of goods in general, and between the buyers and sellers of products in particular.

This confirms the following: the sharing of price and advertising signals of quality by consumers in order to determine the proportion of high-quality and low-quality goods will facilitate to improvement of the selection, reduction of the production of low-quality goods and exclusion low-quality goods from the market by high-quality goods.

\section{Conclusions}

The nature of information asymmetry in the markets of durable goods is that in addition to the well-known nature of the uneven distribution of information of the quality, it's found out an uneven distribution of information between producers and consumers of the market share of high-quality goods and low-quality goods. A direction of reducing information asymmetry is proposed to the market shares of goods of high quality and low quality based on distinguishing producers of high-quality goods and low-quality goods by consumers and by sharing of price and advertising signals of quality. In this case, it is determined that with increasing information asymmetry there is a reduction of the consumer share of high-quality goods compared with low-quality goods, which is accompanied by a shift of the resulting curve asymmetric demand towards the demand curve of low-quality goods and on the contrary. Furthermore, it is found out that the resulting curve of asymmetric demand intersects the curves of the supply of high-goods and low-quality goods in the points causing the two equilibriums:

$$
D_{a u}(p)=S_{k}(p), D_{a u}(p)=S_{H}(p)
$$

the equilibrium at the level of prices $p_{l}$ and volumes $Q_{k}$ of high-quality goods and the equilibrium at the level of prices $p_{2}$ and volumes $Q_{H}$ of low-quality goods. This explains the differentiation of goods by quality in markets with incomplete information.

\section{References}

Audretsch, D. B., \& Lehmann, E. E. (2005, October). Does the knowledge spillover theory of entrepreneurship hold for regions? Research Policy, 34, 1191-1202. http://dx.doi.org/10.1016/j.respol.2005.03.012

Averianov, B. A., Bagautdinova, N. G., \& Sarkin, A. V. (2013). Estimation of manufacturing enterprise development risks in process of operational activity. World Applied Sciences Journal, 27(13), 202-206.

Bagautdinova, N. G., Goncharova, I. V., Shurkina, E. Y., Sarkin, A. V., Averyanov, B. A., \& Svirina, A. A. (2013). Entreprenuerial development in a corrupted environment. Procedia Economic and finance, 5, 73-82. http://dx.doi.org/10.1016/S2212-5671(13)00012-9

Desai, P. S., Koenigsberg, O., \& Purohit, D. (2007, January). The role of production leads time and demand uncertainty in marketing durable goods. Management Science, 53, 150-158. http://dx.doi.org/10.1287/mnsc. 1060.0599

Dowd, K. (1992). The demand for non-durable goods and endogenous labour supply. Applied Economics, 24, 1199-1202. http://dx.doi.org/10.1080/00036849200000129

Jia, J., \& Zhang, J. (2013, July). Dynamic ordering and pricing strategies in a two-tier multi-generation durable goods supply chain. International Journal of Production Economics, 144, 135-142. http://dx.doi.org/10. 1016/j.ijpe.2013.01.029

Markov, V. A., Bagautdinova, N. G., \& Yashin, N. S. (2013). Improvement of instruments of the state cluster-based policy in the contexts of economic entities interrelation asymmetry. World Applied Sciences Journal, 27(13), 130-134.

Marrero, G. A., \& Novales, A., (2007). Income taxes, public investment and welfare in a growing economy. Journal of Economic Dynamics and Control, 31, 3348-3369. http://dx.doi.org/10.1016/j.jedc.2006.10.007

Marshall, A. (1890). Principles of Economics. Macmillan and Company. 
Morgan, N. A., \& Vorhies, D. W. (2001). Product quality alignment and business unit performance. Journal of Product Innovation Management, 18(6), 396-407. http://dx.doi.org/10.1016/S0737-6782(01)00112-6

Nelson, P. (1970). Information and consumer behavior. Journal of Political Economy, 78(2), 311-329. http://dx.doi.org/10.1086/259630

Olney, M. L. (1990, July). Demand for consumer durable goods in 20th century America. Explorations in Economic History, 27, 322-349. http://dx.doi.org/10.1016/0014-4983(90)90017-S

Pace, N. (2004, June). Packaging demand rises. Paperboard Packaging, 89, 10-12.

Panasyuk, M. V., Pudovik, E. M., \& Sabirova, M. E. (2013). Optimization of regional passenger bus traffic network. Procedia Economic and finance, 5, 589-596. http://dx.doi.org/10.1016/S2212-5671(13)00069-5

Pesaran, M. H., Schuermann, T., \& Weiner, S. M. (2004). Modeling Regional Interdependences Using a Global Error-Correcting Macro econometric Model. Journal of Business and Economic Statistics, 22(2), 129-162. http://dx.doi.org/10.1198/073500104000000019

Safiullin, M. R., Elstin, L. A., \& Shakirova, A. I. (2012, July). Evaluation of business and economic activity as a short-term forecasting tool. Herald of the Russian Academy of Sciences, 82, 290-294. http://dx.doi.org/10. 1134/S1019331612040053

Sarkin, A. V., Bagautdinova, N. G., \& Averianov, B. A. (2013a). Development and implementation of adaptive science-intensive manufacture management system based on management processes automation. World Applied Sciences Journal, 27(13), 159-164.

Sarkin, A. V., Bagautdinova, N. G., \& Averianov, B. A. (2013b). Development of science-intensive strategy in machinery-building company in contemporary Russia. World Applied Sciences Journal, 27(13), 24-28.

Tilson, V., \& Zheng, X. (2014, August). Monopoly production and pricing of finitely durable goods with strategic consumers fluctuating willingness to pay. International Journal of Production Economics, 154, 217-232. http://dx.doi.org/10.1016/j.ijpe.2014.04.017

von Mises, L. (1962). The Free and Prosperous Commonwealth: An Exposition of the Ideas of Classical Liberalism. Princeton: Van Nostrand.

\section{Copyrights}

Copyright for this article is retained by the author(s), with first publication rights granted to the journal.

This is an open-access article distributed under the terms and conditions of the Creative Commons Attribution license (http://creativecommons.org/licenses/by/3.0/). 